\title{
Effects of Yoga Poses on Spinal Range of Motion, Posterior Superior Iliac Spine Levels and Muscle Activity According to Pelvic Displacement in Middle-aged Women
}

\author{
Ah-Ram Kim ${ }^{1}$, Sun-Ah Lee ${ }^{2}$, Ho-Seong Lee ${ }^{1,2^{*}}$ \\ 'Namseoul University, Cheonan, Korea \\ ${ }^{2}$ Dankook University, Cheonan, Korea
}

Received: January 23, 2018

Accepted: April 23, 2018

Published online: April 30, 2018

Keywords:

Muscle activity

Pelvic displacement

Posterior superior iliac spine levels

Yoga poses
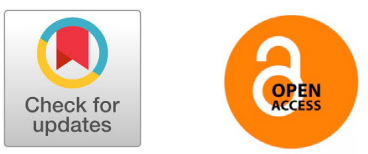

\begin{abstract}
PURPOSE The purpose of this study was to investigate the effects of yoga poses on spinal range of motion, posterior superior iliac spine levels and muscle activity according to pelvic displacement in middle-aged women. METHODS Twenty middle-aged women were selected to normal pelvic displacement group (CON, n=6), anterior pelvic tilt group ( $A P G, n=6$ ) and posterior pelvic tilt group ( $P P G, n=8$ ). Spinal range of motion, posterior superior iliac spine levels and muscle activity were measured during Yoga poses (Janusirsa asana, parivrrta upavistha konasana, parsva upavistha konasana, virabaddra asana III).

RESULTS The following were the main results. Right trunk flexion and pelvic tilt during right janushirasana asana were significantly decreased at APG and PPG compared to $\mathrm{CON}$ ( $p<.05$, respectively). Also, pelvic tilt during right parivrrta upavistha konasana was significantly decreased at APG and PPG compared to $C O N$ ( $p<.05$, respectively). Furthermore, muscle activity in the erector spine, glutes medius, biceps femoris, and gastrocnemius during yoga poses were significantly increased at APG compared to $\operatorname{CON}(p<.05$, respectively), and muscle activity in the glutes medius during yoga poses was significantly increased at PPG compared to CON $(p<.05)$.

CONCLUSIONS These results confirms that yoga poses in middle-aged women with pelvic displacement make a negative effect on spinal joint motion range, posterior superior iliac spine levels and muscle activity.
\end{abstract}

( The Asian Society of Kinesiology and the Korean Academy of Kinesiology

서론

골반(pelvis)은 신체의 무게중심을 다리로 전달하고 (Kang \& Kim, 2011), 몸통의 운동범위를 증가시키는 기능 을 담당하며(Bae et al., 1999), 다리 근육의 원천이다(Park $\&$ Park, 2004). 또한 다리의 움직임은 골반을 중심으로 신 체 무게중심을 인체의 다방향(divergent)으로 이동시키는

*Correspondence: Ho-Seong Lee, Dankook University, 119, Dandae-ro, Dongnam-gu, Cheonan-si, Chungnam, 31116, Republic of Korea.

E-mail:hoseh28@dankook.ac.kr
데 골반과 다리의 자세정렬과 움직임이 바르지 않으면 골 반의 변형을 가져올 수 있다(Kendall et al., 1993). 이러한 자 세적 보상에 따른 골반변위(pelvic displacement), 즉, 골반 의 앞 기울임 및 뒤 기울임의 변위는 다리의 기능적인 단 축과 비대칭적 근육발달 때문에 발생한다고 알려져 있으 며, 특히, 중년 여성은 임신과 출산을 경험하며 골반에 다 양한 변화가 발행하는데(Choi, 2008), 임신으로 인해 복부 는 앞으로 나오게 되고 허리뼈와 골반은 뒤로 움직이게 되 면서 복부 근육들이 느슨해지고, 약해지면서 골반변위가 일어나게 되어 다양한 근골격계 질환을 야기한다고 보고 하였다(Sahrmann, 2002). 따라서 중년여성과 골반변위는 
밀접한 관련성이 있다고 생각된다.

골반 위치의 변형 중 골반 앞 기울임(anterior pelvic tilt; $\mathrm{APT}$ )은 복부 근육의 약화, 넙다리 뒷근육 및 엉덩관절 벌 림근의 약화, 척주 주변근, 엉덩관절 굽힘근의 경직 및 유 연성 감소가 주원인이며(Levine et al., 1997), 반면에 골반 뒤 기울임(posterior pelvic tilt; PPT)은 복부 근육, 넙다리 뒷근육 및 엉덩관절 벌림근의 경직 및 유연성 감소와 척 주 주변근, 엉덩관절 굽힘근의 약화가 주원인이다(Min, 2005). 이와 같이 골반의 움직임 중 시상면에서 발생하는 $\mathrm{APT}$ 와 $\mathrm{PPT}$ 의 비대칭은 무릎과 엉덩관절을 앞으로 굽히 게 하여 허리뼈 기울임(lordotic posture)의 각도를 증가시 켜 골반의 앞과 뒤의 운동범위를 감소시키며(Kim et al., 1997), 또한 APT와 PPT의 비대칭은 몸통과 다리에도 영 향을 미쳐서 자세의 안정성과 움직이는 균형에도 부정적 인 영향을 미친다고 보고하였다(Kim, 2014). 일반적으로, 골반 운동은 엉덩관절과 다리의 개입을 최소화시켜 자세 안정성을 향상시킬 수 있으며(Bae et al., 1999; Graves et al., 1990), 골반 근육의 적절한 동시수축을 자극하여 골반의 평형, 척추자세조절, 엉덩관절의 활동성 및 정상적인 근 육 긴장을 유지시킬 수 있다(Kim \& Jang, 2014). 앞서 언급 한 것처럼, $\mathrm{APT}$ 와 $\mathrm{PPT}$ 의 움직임은 척추에 영향을 미치고 몸통 자세를 조절하는 중요한 역할을 하는데도 불구하고 (Kong et al., 2015; Osamu et al., 2014), 이러한 골반의 변위 에 대한 고려 없이 진행되는 운동은 그 효과도 미비할 뿐 만 아니라 골반의 변위를 악화시킬 가능성이 있다고 생 각된다.

한편, 요가 동작(yoga poses)은 반복적인 등척성 수축 과 이완을 통해 근력, 균형을 증가시키고(Yun et al., 2009; Choi, 2007), 척추와 골반 근육의 이완을 촉진하여, 골반 의 앞 기울임의 감소와 견인력을 제공한다(kimberly et al., 2005). 요가는 신체의 자세와 정렬이 매우 중요하다고 알 려져 있으며(Oken et al., 2006), 많은 동작들이 신체의 골 반을 중심으로 다리의 움직임과 지지가 필요한 역할을 담당하고 있다. 선행연구에 의하면, 요가는 골반의 가동 성을 증가시켜 좌.우 다리 길이 차이를 유의하게 감소시 키고, 엉덩뼈 높이 변화에 영향을 미친다고 보고하였다 (Choi, 2008). 따라서 요가 동작은 골반 및 엉덩관절의 안 정성과 가동성을 유지하는데 중요하며(Iyengar, 1989; Leslie, 2007), 균형 상태에서 중립 상태의 골반을 중심으로 안 정성 있게 이행할 수 있도록 하는 것이 효과적이라고 생 각된다. 선행연구에 의하면, 요가 동작에서 불균형한 움
직임은 신체의 지속적인 불균형을 초래하며(Schamberger, 2012), 특히 골반의 변위는 신체 중심부의 불안정성을 발생시켜서 요가 동작에서 서거나 앉는 등의 바른 자세 유지를 어렵게 한다고 보고하였다(Neumann, 2002). 이와 같이 요가 동작 중 불균형한 움직임으로 인한 골반의 문 제를 예방하고 치료하기 위해서는 신체의 안정성과 정렬 이 중요하다(Evans et al., 2013; Iyengar, 1970). 선행연구에 의하면, 요가 동작은 숙련도에 따라 관절가동범위와 근 활성도가 현저한 차이를 나타내게 되는데 이는 숙련자와 비숙련자가 활성화 되는 근육이 다르기 때문이라고 보고 하였다(You et al., 2002). 이에 따라 각기 다른 요가 동작 시 발현되는 주 근육을 정확히 인지하는 것이 중요하다고 생 각된다. 하지만 골반변위에 따른 요가 동작이 골반과 엉 덩관절 및 주변 근육에 어떠한 영향을 미치는가에 대해서 실천적으로 검토한 연구는 부족한 실정이다.

따라서 이 연구에서는 APT 및 PPT의 골반변위를 갖고 있는 중년여성을 대상으로 요가 동작이 척추 관절가동범 위, 위뒤엉덩뼈가시의 높이 및 근활성도에 어떠한 영향을 미치는가를 검토하는데 그 목적이 있다.

\section{연구방법}

\section{연구대상}

이 연구에서는 중년여성을 대상으로 X-ray 검사를 통 해 선행연구를 바탕으로 허리척추앞굽음각(lumbar lordosis)을 측정하여 허리척추앞굽음각이 $45^{\circ}$ 의 정상인 통 제 집단(control group; $\mathrm{CON}, \mathrm{n}=6$ ), 허리척추앞굽음각이 $45^{\circ}$ 이상의 골반 앞기울임 집단(anterior pelvic tilt group; $\mathrm{APG}, \mathrm{n}=6$ ) 및 허리척추앞굽음각이 $45^{\circ}$ 이하인 골반 뒤 기울임 집단(posterior pelvic tilt group; PPG, $\mathrm{n}=8$ )으로 분 류하였다(Neumann, 2002). 이 연구에서는 연구 대상자 선 정을 위해 G-power 3.1.9.2 프로그램을 이용하였으며, 유 의수준 <.05, 효과크기 <.025, 검정력 <.95에서 산출하였 을 때 적절한 총 표본수는 20명이 요구되었다(Faul et al, 2007). 연구 대상자는 모든 피험자는 수술이나 시술을 받 은 자는 제외하였으며, 각 피험자는 실험 기간 중에 개인 적인 격렬한 신체활동, 약제복용 및 음주를 금지시켰다. 모든 피험자는 연구의 취지내용을 충분히 이해한 후 자발 적으로 실험에 참여하였다. 피험자의 신체적 특성은 < Table $1>$ 과 같다. 이 연구는 남서울대학교 기관생명윤리위 원회(IRB)의 심의를 거쳐 진행되었다. 


\begin{tabular}{|cccccc|}
\hline \multicolumn{7}{|c|}{ Table 1. Physical characteristic of subjects. } \\
\hline $\begin{array}{c}\text { Group } \\
\text { (n) }\end{array}$ & $\begin{array}{c}\text { Age } \\
\text { (yrs) }\end{array}$ & $\begin{array}{c}\text { Height } \\
(\mathbf{c m})\end{array}$ & $\begin{array}{c}\text { Weight } \\
\text { (kg) }\end{array}$ & $\begin{array}{c}\text { Body fat } \\
(\%)\end{array}$ & $\begin{array}{c}\text { BMI } \\
\left(\mathbf{k g} / \mathrm{m}^{2}\right)\end{array}$ \\
\hline CON & 52.67 & 156.63 & 60.17 & 31.08 & 24.50 \\
$(6)$ & \pm 12.58 & \pm 2.19 & \pm 9.28 & \pm 4.66 & \pm 3.56 \\
APG & 47.50 & 162.7 & 58.07 & 21.92 & 27.00 \\
(6) & \pm 8.69 & $2 \pm 5.01$ & \pm 8.04 & \pm 2.69 & \pm 5.97 \\
PPG & 51.00 & 158.05 & 58.05 & 23.24 & 32.64 \\
(8) & \pm 12.47 & \pm 5.32 & \pm 6.25 & \pm 2.32 & \pm 3.41 \\
\hline \multicolumn{7}{l}{ Values are means \pm SD } & & & & \\
\hline
\end{tabular}

\section{실험절차}

모든 대상자는 신체조성과 4 가지의 요가 동작(Janusirsa asana, parivrrta upavistha konasana, parsva upavistha konasana, virabaddra asana III) 중에 왼쪽과 오른쪽의 몸통 및 골반의 굽힘(L-flexion, R-flexion), 왼쪽과 오른쪽 몸통 의 왼쪽(L)과 오른쪽(R) 위뒤엉덩뼈가시 높이, 그리고 동 일한 요가 동작 중에 왼쪽의 척추세움근(L-ES), 중간볼기 근(L-GM), 넙다리두갈래근 $(\mathrm{L}-\mathrm{BF})$ 및 장딴지근(L-GN)과 오른쪽의 척추세움근(R-ES), 중간 볼기근(R-GM), 넙다리 두갈래근(R-BF) 및 장딴지근(R-GN)의 활성도를 측정한 후에 집단 간의 비교를 실시하였다.

\section{객관적 위험인자 지표}

신체조성 신체조성은 생체전기저항법을 이용한 체성 분 측정기(Inbody 770, Korea)를 사용하여 체중 $(\mathrm{kg})$ 과 체지 방율 $(\%)$ 을 측정하였고, $\mathrm{BMI}\left(\mathrm{kg} / \mathrm{m}^{2}\right)$ 를 산출하였다.

요가 동작 중 척추 관절가동범위 요가 동작 중 척추 관절가동범위는 Hocoma 무선 척추 관절가동범위측정기
(ValedoMotion, Hocoma)를 이용하여 왼쪽(Left, L)과 오른 쪽 몸통(Right, R)의 옆 굽힘, 앞 굽힘, 돌림, 그리고 왼쪽 (Left, L)과 오른쪽 골반(Right, R)의 골반 옆기울임, 골반 의 뒤방향 및 앞방향 기울임을 측정하였다<Figure 1>. 감 지기는 총 3 곳에 부착하였으며, 복장뼈센서(Sternum sensor)는 복장뼈자루에서 손가락 2개 너비만큼 아래에 부착 하였고, 천골센서(Sacrum sensor)는 S1 척추에 부착하였으 며, 요추센서(Lumbar sensor)는 L1 척추에 부착하였다. 피 부저항으로 생기는 오차를 줄이기 위하여 알코올 솜으로 부착부위를 닦은 후 부착하였다.

요가 동작 중 위뒤엉덩뼈가시의 높이 요가 동작 중 위 뒤엉덩뼈가시(posterior superior lilac spine)의 높이는 엉덩 이의 후면에서 줄자를 이용하여 왼쪽 및 오른쪽 몸통의 엉덩뼈가시의 정점을 바닥에서부터 높이를 측정하였다.

요가 동작 중 근활성도 근전도 신호는 Delsys trigno 무선 근전도(Delsys trigon wireless EMG system, Delsys Inc., Boston, MA, USA)를 이용하여 수집하였다<Figure 2>. 근 전도의 표본 수집률(sampling rate)은 $1,000 \mathrm{~Hz}$ 로 하였고, 주파수 대역폭은 20 45 Hz의 대역통과필터(bandpass filter)를 적용하고, 동상제거비율(common mode rejection ratio)은 $100 \mathrm{~dB}$ 이상, 초기 잡음(baseline noise)은 $1 \mathrm{mV}$ 이하 및 입력 저항값(input impedance)은 $100 \mathrm{mOhms}$ 이상으로 설정하였다. 각 근육에서 수집된 표면 근전도 신호는 Delsys EMG 분석 소프트웨어(Delsys EMG Works Acqusition, Delsys Inc., Boston, MA, USA)를 사용하였다. 근전도 신호 는 왼쪽(Left; L) 및 오른쪽(Right; R) 척추세움근(Erector spine; ES), 중간볼기근(Glutes medius; GM), 넙다리두갈래 근(Biceps femoris; $\mathrm{BF}$ ) 및 장딴지근(Gastrocnemius; $\mathrm{GN})$ 을

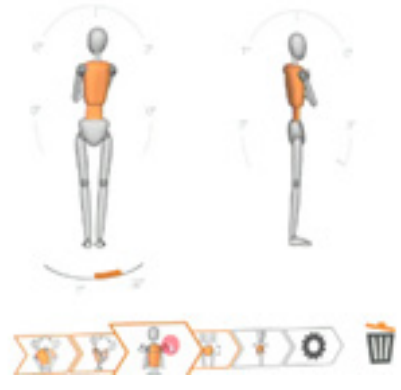

Figure 1. Range of motion of spine

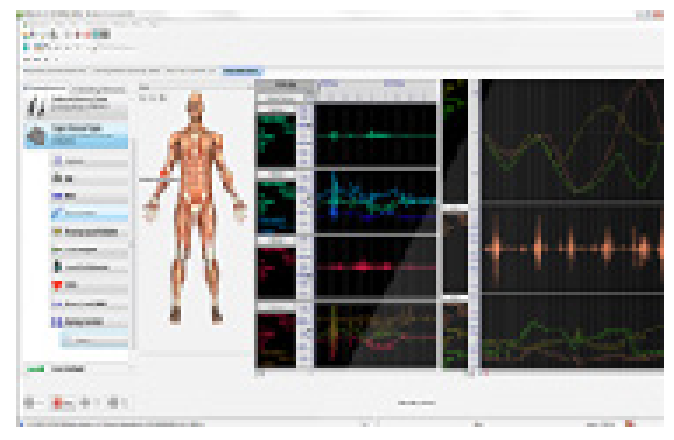

Figure 2. EMG 


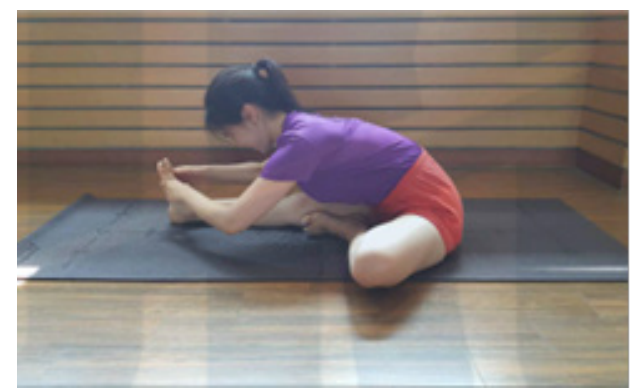

Figure 3. Janusirsa asana

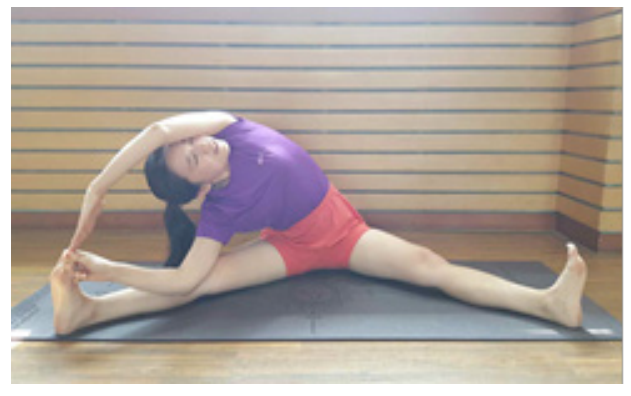

Figure 4. Parivrrta upavistha konasana

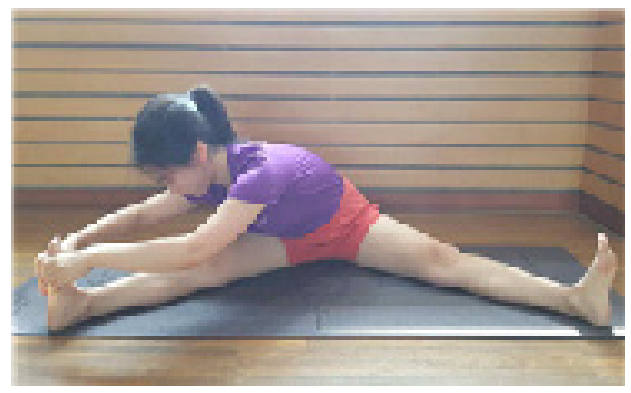

Figure 5. Parsva upavistha konasan

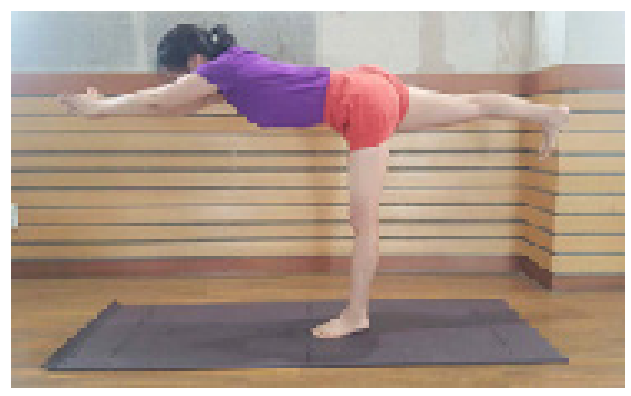

Figure 6. Virabaddra asana III

측정하였다. ES의 전극은 두 번째 허리뼈(L2)에서 오른쪽, 왼쪽으로 $2 \mathrm{~cm}$ 지점에 부착하였고, $\mathrm{GM}$ 의 전극은 엉덩뼈 바깥쪽 위부분과 정지점인 넙다리뼈 큰 돌기의 바깥쪽 면 사이 $1 / 2$ 지점 근육의 가장 발달된 부위에 부착하였고, $\mathrm{BF}$
의 전극은 녑다리뼈의 뒤쪽 외측 면에서 궁둥뼈 거친면의 $1 / 2$ 지점에 부착하였으며, $\mathrm{GN}$ 의 전극은 종아리빼머리와 발꿈치뼈융기의 $1 / 2$ 지점에 부착하였다. 전극을 고정하 는 부위는 최대 근 수축 유도 시에 뚜렷하게 보이는 근복 (muscle belly)에 부착한 뒤 근활성도의 정규화를 위해서 각 근육의 최대 수의적 등척성 근수축(maximal voluntary isometric contraction; MVIC)을 요가 동작 전에 실시하였 다. 근활성도는 각 요가 동작별로 측정하였고, 측정 오차 를 줄이기 위해 측정 사이 5 분씩 휴식을 하였으며 총 5 회 측정한 값의 평균값을 사용하였다(Nooij et al., 2009). 산출 된 근전도 파형을 RMS(root mean square)값으로 도출 한 후 사전에 측정된 MVIC에 각 근육을 대비하여 \% MVIC값 으로 정량화 하였다.

\section{요가동작}

이 연구에서 요가 동작은 Yoga Dipika (2007)와 Yoga Anatomu (2011)에 기술되어 있는 요가의 몸통 굽힘 동작 중에 척추의 가동범위를 확인할 수 있는 대표적인 4 가지 (Janusirsa asana, parivrrta upavistha konasana, parsva upavistha konasana, virabaddra asana III)를 이 연구에 맞게 수정 및 보완하여 구성하였다. Janusirsa asana 동작은 두 다리 를 앞으로 쭉 편 자세에서 왼쪽 넓적다리와 왼쪽 장단지 의 바깥쪽이 바닥에 닿도록 왼쪽 무릎을 굽혀서 왼쪽으로 $120^{\circ}$ 벌리고 왼쪽 발뒤꿈치를 회음 가까이의 왼쪽 넓적 다리 안쪽에 밀착시켰으며, 팔은 쭉 뻗어 양손으로 발을 잡고, 오른쪽 무릎의 뒤쪽을 바닥에 닿게 하여 몸통을 앞 으로 굽히며 오른다리가 오른쪽으로 기울지 않도록 하였 다<Figure 3>.

Parivrrta upavistha konasana 동작은 다리를 좌우로 쭉 편 자세에서 다리의 각도는 둔각 $\left(90^{\circ}\right.$ 보다 작은 크고 $180^{\circ}$ 보다 작은 각)이 되게 벌린 후, 뒤꿈치 축의 중앙은 바닥을 누른 상태로 발바닥은 앞을, 발끝은 위로 향하게 한 후 오른 팔을 오른 다리 쪽으로 뻗어 오른발 안쪽 면을 잡고 몸통을 뒤로 젖혀 왼쪽 팔은 오른발의 바깥쪽을 잡 아 몸통을 위로 튼 자세를 유지하였다<Figure 4>.

Parsva upavistha konasana 동작은 다리를 좌우로 쭉 편 자세에서 다리의 각도는 둔각 $\left(90^{\circ}\right.$ 보다 작은 크고 $180^{\circ}$ 보다 작은 각)이 되게 벌린 후, 뒤꿈치 축의 중앙은 바닥을 누르고 발바닥은 앞을, 발끝은 위를 향하게 한 후 양 팔을 오른 다리 쪽으로 뻗어 오른발을 잡고 상체를 오른 다리 위로 굽히게 하여 왼쪽 엉덩이와 넓적다리 뒤 부분이 들 


\begin{tabular}{|c|c|c|c|c|c|c|}
\hline Yoga poses & Position & Direction & $\operatorname{CON}(n=6)$ & APG $(n=6)$ & PPG $(n=8)$ & $\mathrm{F}$ \\
\hline \multirow{8}{*}{ Janusirsa asana } & \multirow{2}{*}{ Left trunk } & L-flexion & $10.67 \pm 10.27$ & $7.50 \pm 9.61$ & $13.71 \pm 13.76$ & 3.534 \\
\hline & & R-flexion & $27.00 \pm 18.69$ & $13.50 \pm 10.84$ & $22.29 \pm 21.85$ & 0.220 \\
\hline & \multirow{2}{*}{ Right trunk } & L-flexion & $18.00 \pm 6.87$ & $12.67 \pm 12.01$ & $18.14 \pm 17.19$ & 1.669 \\
\hline & & R-flexion & $58.17 \pm 33.52$ & $17.33 \pm 11.43^{\dagger}$ & $26.29 \pm 29.72^{\dagger}$ & $3.771^{*}$ \\
\hline & \multirow{2}{*}{ Left pelvic } & L-flexion & $37.17 \pm 26.56$ & $39.00 \pm 24.10$ & $38.71 \pm 31.03$ & 0.352 \\
\hline & & R-flexion & $38.83 \pm 29.08$ & $15.00 \pm 10.75$ & $18.86 \pm 23.48$ & 0.131 \\
\hline & \multirow{2}{*}{ Right pelvic } & L-flexion & $32.50 \pm 20.95$ & $39.00 \pm 20.07$ & $38.43 \pm 30.28$ & 1.900 \\
\hline & & R-flexion & $37.00 \pm 28.53$ & $9.33 \pm 5.01^{\dagger}$ & $13.43 \pm 12.47^{\dagger}$ & $3.859^{*}$ \\
\hline \multirow{8}{*}{$\begin{array}{l}\text { Parivrrta upavistha } \\
\text { konasana }\end{array}$} & \multirow{2}{*}{ Left trunk } & L-flexion & $10.67 \pm 10.27$ & $7.50 \pm 9.61$ & $13.71 \pm 13.76$ & 0.324 \\
\hline & & R-flexion & $27.00 \pm 18.69$ & $13.50 \pm 10.84$ & $22.29 \pm 21.85$ & 2.433 \\
\hline & \multirow{2}{*}{ Right trunk } & L-flexion & $32.00 \pm 33.49$ & $31.00 \pm 31.36$ & $16.71 \pm 13.63$ & 0.393 \\
\hline & & R-flexion & $82.50 \pm 45.11$ & $76.00 \pm 44.86$ & $57.00 \pm 51.54$ & 0.724 \\
\hline & \multirow{2}{*}{ Left pelvic } & L-flexion & $34.50 \pm 29.51$ & $13.50 \pm 9.27$ & $20.57 \pm 12.95$ & 1.071 \\
\hline & & R-flexion & $85.50 \pm 49.00$ & $89.33 \pm 64.78$ & $68.14 \pm 59.87$ & 0.666 \\
\hline & \multirow{2}{*}{ Right pelvic } & L-flexion & $35.17 \pm 16.89$ & $37.50 \pm 22.17$ & $30.86 \pm 26.40$ & 0.285 \\
\hline & & R-flexion & $21.33 \pm 12.40$ & $9.17 \pm 9.58$ & $22.00 \pm 23.98$ & 1.071 \\
\hline \multirow{8}{*}{$\begin{array}{l}\text { Parsva upavistha } \\
\text { konasana }\end{array}$} & \multirow{2}{*}{ Left trunk } & L-flexion & $18.00 \pm 11.58$ & $29.50 \pm 29.14$ & $22.43 \pm 17.76$ & 1.900 \\
\hline & & R-flexion & $106.50 \pm 54.17$ & $79.83 \pm 55.40$ & $70.29 \pm 60.92$ & 2.433 \\
\hline & \multirow{2}{*}{ Right trunk } & L-flexion & $17.50 \pm 9.35$ & $13.50 \pm 8.02$ & $23.57 \pm 11.47$ & 0.302 \\
\hline & & R-flexion & $61.83 \pm 40.48$ & $61.00 \pm 51.21$ & $50.43 \pm 59.09$ & 0.964 \\
\hline & \multirow{2}{*}{ Left pelvic } & L-flexion & $30.83 \pm 21.57$ & $45.00 \pm 28.55$ & $34.57 \pm 30.42$ & 0.248 \\
\hline & & R-flexion & $42.67 \pm 34.11$ & $17.33 \pm 6.15$ & $28.14 \pm 25.30$ & 1.669 \\
\hline & \multirow{2}{*}{ Right pelvic } & L-flexion & $33.17 \pm 24.64$ & $51.83 \pm 22.36$ & $44.86 \pm 29.33$ & 0.131 \\
\hline & & R-flexion & $47.83 \pm 23.95$ & $16.50 \pm 7.87^{\dagger}$ & $21.00 \pm 15.89^{\dagger}$ & $4.236^{*}$ \\
\hline \multirow{8}{*}{ Virabaddra Asana II } & \multirow{2}{*}{ Left trunk } & L-flexion & $37.33 \pm 27.09$ & $19.50 \pm 19.21$ & $17.14 \pm 16.31$ & 1.759 \\
\hline & & R-flexion & $31.17 \pm 42.76$ & $32.00 \pm 31.36$ & $38.43 \pm 23.54$ & 0.475 \\
\hline & \multirow{2}{*}{ Right trunk } & L-flexion & $34.67 \pm 29.85$ & $23.00 \pm 7.95$ & $17.71 \pm 10.16$ & 1.577 \\
\hline & & R-flexion & $33.50 \pm 31.49$ & $33.00 \pm 32.09$ & $14.57 \pm 8.58$ & 2.982 \\
\hline & \multirow{2}{*}{ Left pelvic } & L-flexion & $42.83 \pm 46.73$ & $68.33 \pm 20.87$ & $68.29 \pm 25.43$ & 0.681 \\
\hline & & R-flexion & $71.00 \pm 28.38$ & $49.83 \pm 19.83$ & $53.57 \pm 27.53$ & 0.436 \\
\hline & \multirow{2}{*}{ Right pelvic } & L-flexion & $49.33 \pm 43.59$ & $55.50 \pm 36.57$ & $67.86 \pm 20.38$ & 0.565 \\
\hline & & R-flexion & $49.33 \pm 43.59$ & $49.50 \pm 16.63$ & $58.00 \pm 22.08$ & 1.805 \\
\hline
\end{tabular}

뜨지 않도록 하였다<Figure 5>.

Virabaddra asana III 동작은 바르게 선 자세에서 다리 는 $120 \mathrm{~cm}$ 정도 옆으로 벌려 오른 발은 오른쪽으로 $90^{\circ}$, 왼 발은 안쪽으로 $60^{\circ}$ 돌리고, 몸통을 돌려 선 후 오른 다 리의 무릎은 $90^{\circ}$ 구부린 상태에서 상체를 굽혀 넓적다리 위에 가슴을 대고 왼 다리를 들어 올리고 오른 다리를 쭉 편 후, 오른다리는 바닥과 수직으로 왼 다리는 넓적다리 의 앞면이 바닥과 평행이 되도록 하였다<Figure 6>.

\section{자료처리}

모든 자료는 SPSS WIN Ver 20.0을 이용하여 평균과 표 준편차를 산출하였다. 집단 간에 차이를 규명하기 위하 여 일원반복측정 분산분석(One-way repeated measures ANOVA)을 실시하였으며, 집단 간에 통계적으로 유의한 차이가 있을 경우 사후검정(LSD)에 따른 다중비교를 실 시하였다. 통계적 유의수준은 $\mathrm{a}=.05$ 로 설정하였다. 


\begin{tabular}{|c|c|c|c|c|c|c|}
\hline Yoga poses & Position & Direction & $\operatorname{CON}(n=6)$ & APG $(n=6)$ & PPG $(n=8)$ & $\mathrm{F}$ \\
\hline \multirow{4}{*}{ Janusirsa asana } & \multirow{2}{*}{ Left trunk } & $\mathrm{L}$ & $22.03 \pm 3.82$ & $19.32 \pm 3.98$ & $20.79 \pm 3.38$ & 0.804 \\
\hline & & $\mathrm{R}$ & $21.07 \pm 3.72$ & $17.15 \pm 3.07$ & $18.09 \pm 2.80$ & 1.962 \\
\hline & \multirow{2}{*}{ Right trunk } & L & $19.62 \pm 2.24$ & $17.15 \pm 3.07$ & $19.44 \pm 3.83$ & 0.409 \\
\hline & & $\mathrm{R}$ & $21.90 \pm 3.34$ & $19.47 \pm 3.44$ & $20.79 \pm 1.81$ & 1.091 \\
\hline \multirow{4}{*}{$\begin{array}{l}\text { Parivrrta upavistha } \\
\text { konasana }\end{array}$} & \multirow{2}{*}{ Left trunk } & L & $21.92 \pm 4.18$ & $17.83 \pm 2.68$ & $18.81 \pm 3.01$ & 1.160 \\
\hline & & $\mathrm{R}$ & $23.32 \pm 2.48$ & $20.75 \pm 2.91$ & $22.54 \pm 3.77$ & 0.839 \\
\hline & \multirow{2}{*}{ Right trunk } & L & $23.97 \pm 3.36$ & $20.87 \pm 2.73$ & $21.91 \pm 2.45$ & 1.059 \\
\hline & & $\mathrm{R}$ & $19.12 \pm 1.62$ & $16.90 \pm 1.70$ & $17.96 \pm 1.71$ & 2.618 \\
\hline \multirow{4}{*}{$\begin{array}{l}\text { Parsva upavistha } \\
\text { konasana }\end{array}$} & \multirow{2}{*}{ Left trunk } & L & $19.53 \pm 1.70$ & $18.43 \pm 2.28$ & $19.46 \pm 2.05$ & 1.845 \\
\hline & & $\mathrm{R}$ & $22.43 \pm 1.86$ & $22.40 \pm 1.70$ & $22.93 \pm 2.04$ & 1.058 \\
\hline & \multirow{2}{*}{ Right trunk } & L & $22.83 \pm 1.75$ & $23.17 \pm 1.51$ & $23.41 \pm 3.30$ & 2.475 \\
\hline & & $\mathrm{R}$ & $21.23 \pm 3.82$ & $18.80 \pm 1.71$ & $19.44 \pm 1.93$ & 1.396 \\
\hline \multirow{4}{*}{ Virabaddra Asana III } & \multirow{2}{*}{ Left trunk } & L & $94.57 \pm 2.30$ & $97.54 \pm 5.13$ & $95.34 \pm 5.70$ & 0.095 \\
\hline & & $\mathrm{R}$ & $88.53 \pm 3.42$ & $91.98 \pm 4.11$ & $90.27 \pm 3.12$ & 0.165 \\
\hline & \multirow{2}{*}{ Right trunk } & L & $92.13 \pm 7.64$ & $92.13 \pm 7.64$ & $90.49 \pm 3.30$ & 0.563 \\
\hline & & $\mathrm{R}$ & $91.20 \pm 3.76$ & $97.50 \pm 3.57^{\dagger}$ & $93.89 \pm 3.08$ & $5.011^{*}$ \\
\hline
\end{tabular}

\section{결 과}

\section{요가 동작 중 척추 관절가동범위}

요가 동작 중 척추 관절가동범위는 <Table 2>에 제시한 바와 같다. Janusirsa asana 동작 중 오른쪽 몸통에서 L-flexion은 $\mathrm{CON}$ 과 비교해서 $\mathrm{APG}(\mathrm{p}=.024)$ 및 $\mathrm{PPG}(\mathrm{p}=.036)$ 에 서 유의하게 낮게 나타났으며, 오른쪽 골반에서 R-flexion 은 $\mathrm{CON}$ 과 비교해서 $\mathrm{APG}(\mathrm{p}=.018)$ 및 $\mathrm{PPG}(\mathrm{p}=.049)$ 서 유의 하게 낮게 나타났다. 또한 Parsva upavistha konasana 동작 중 오른쪽 골반에서 R-flexion은 $\mathrm{CON}$ 과 비교해서 $\mathrm{APG}$ $(\mathrm{p}=.017)$ 및 $\mathrm{PPG}(\mathrm{p}=.031)$ 에서 유의하게 낮게 나타났다. 하 지만 Parivrrta upavistha konasana 및 Virabaddra Asana III 동작 중 몸통 및 골반의 척추 관절가동범위는 모든 방향 에서 집단 간에 통계학적으로 유의한 차이가 나타나지 않 았다.

\section{요가 동작 중 위뒤엉덩뼈가시 높이}

요가 동작 중 위뒤엉덩뼈가시 높이는 < Table 3>에 제 시한 바와 같다. Virabaddra asana III 동작 중 오른쪽 몸통 에서 오른쪽 위뒤엉덩뼈가시의 높이는 $\mathrm{CON}$ 과 비교해서 $\mathrm{APG}(\mathrm{p}=.006)$ 에서 유의하게 높게 나타났다. 하지만 Janu- sirsa asana, Parivrrta upavistha konasana 및 Parsva upavistha konasana 동작 중 위뒤엉덩뼈가시 높이는 모든 방향에서 집단 간에 통계학적으로 유의한 차이가 나타나지 않았다.

\section{요가 동작 중 근활성도}

요가 동작 중 근활성도는 <Table 4 >에 제시한 바 와 같다. 왼쪽 Janusirsa asana 동작 중 $\mathrm{L}-\mathrm{ES}(\mathrm{p}=.000)$, $\mathrm{R}-\mathrm{GM}(\mathrm{p}=.001), \mathrm{R}-\mathrm{BF}(\mathrm{p}=.000)$ 및 $\mathrm{R}-\mathrm{GN}(\mathrm{p}=.000)$ 의 근활성 도는 $\mathrm{CON}$ 과 비교해서 $\mathrm{APG}$ 에서 각각 유의하게 높게 나 타났으며, 반면에 $\mathrm{L}-\mathrm{BF}(\mathrm{p}=.000)$ 및 $\mathrm{L}-\mathrm{GL}(\mathrm{p}=.006)$ 의 근활 성도는 $\mathrm{CON}$ 과 비교해서 $\mathrm{APG}$ 에서 각각 유의하게 낮 게 나타났다. 또한 $\mathrm{R}-\mathrm{GM}(\mathrm{p}=.000)$ 의 근활성도는 $\mathrm{CON}$ 과 비교해서 $\mathrm{PPG}$ 에서 유의하게 높게 나타났으며, 반면 에 $\mathrm{L}-\mathrm{BF}(\mathrm{p}=.000), \mathrm{L}-\mathrm{GN}(\mathrm{p}=.000)$ 및 $\mathrm{R}-\mathrm{ES}(\mathrm{p}=.040)$ 의 근활 성도는 $\mathrm{CON}$ 과 비교해서 $\mathrm{PPG}$ 에서 각각 유의하게 낮게 나타났다. 오른쪽 Janusirsa asana 동작 중 $\mathrm{L}-\mathrm{ES}(\mathrm{p}=.000)$, $\mathrm{R}-\mathrm{GM}(\mathrm{p}=.000), \mathrm{R}-\mathrm{BF}(\mathrm{p}=.000)$ 및 $\mathrm{R}-\mathrm{GN}(\mathrm{p}=.000)$ 의 근활성 도는 $\mathrm{CON}$ 과 비교해서 $\mathrm{APG}$ 에서 유의하게 높게 나타 났으며, 반면에 $\mathrm{L}-\mathrm{GM}(\mathrm{p}=.006)$ 의 근활성도는 $\mathrm{CON}$ 과 비 교해서 $\mathrm{APG}$ 에서 유의하게 낮게 나타났다. 또한 L-ES$(\mathrm{p}=.000)$ 및 $\mathrm{R}-\mathrm{GM}(\mathrm{p}=.000)$ 의 근활성도는 $\mathrm{CON}$ 과 비교 해서 PPG에서 각각 유의하게 높게 나타났으며, 반면에 


\begin{tabular}{|c|c|c|c|c|c|c|}
\hline Yoga poses & Direction & Muscles & $\operatorname{CON}(n=6)$ & APG $(n=6)$ & PPG $(n=8)$ & $\mathrm{F}$ \\
\hline \multirow{16}{*}{ Janusirsa asana } & \multirow{8}{*}{ Left } & L-ES & $35.44 \pm 1.61$ & $42.93 \pm 4.48^{\dagger}$ & $34.62 \pm 1.00$ & $18.905^{*}$ \\
\hline & & L-GM & $13.30 \pm 0.49$ & $10.19 \pm 1.83$ & $9.25 \pm 6.03$ & 1.413 \\
\hline & & L-BF & $14.85 \pm 2.48$ & $8.90 \pm 0.40^{\dagger}$ & $6.61 \pm 1.57^{\dagger}$ & $48.452^{*}$ \\
\hline & & L-GN & $29.59 \pm 0.75$ & $27.83 \pm 1.50^{\dagger}$ & $19.85 \pm 0.31^{\dagger}$ & $193.511^{*}$ \\
\hline & & R-ES & $27.86 \pm 24.58$ & $24.14 \pm 10.29$ & $9.34 \pm 1.77^{\dagger}$ & $2.846^{*}$ \\
\hline & & R-GM & $17.77 \pm 0.66$ & $41.08 \pm 3.12^{\dagger}$ & $47.41 \pm 15.51^{\dagger}$ & $15.249^{*}$ \\
\hline & & $\mathrm{R}-\mathrm{BF}$ & $4.73 \pm 0.61$ & $10.35 \pm 1.04^{\dagger}$ & $2.84 \pm 0.21$ & $202.524^{*}$ \\
\hline & & R-GN & $7.18 \pm 1.31$ & $15.93 \pm 2.95^{\dagger}$ & $5.21 \pm 0.36$ & $61.673^{*}$ \\
\hline & \multirow{8}{*}{ Right } & L-ES & $88.61 \pm 8.86$ & $90.60 \pm 3.90$ & $52.49 \pm 0.90^{\dagger}$ & $104.427^{*}$ \\
\hline & & L-GM & $17.89 \pm 2.14$ & $10.57 \pm 0.71^{\dagger}$ & $7.86 \pm 1.30$ & $73.302^{*}$ \\
\hline & & L-BF & $16.23 \pm 3.51$ & $6.70 \pm 2.84^{\dagger}$ & $3.01 \pm 0.08$ & $46.288^{*}$ \\
\hline & & L-GN & $29.87 \pm 0.95$ & $1.46 \pm 0.13^{\dagger}$ & $8.38 \pm 0.84$ & $2528.096^{*}$ \\
\hline & & R-ES & $21.47 \pm 9.95$ & $33.54 \pm 32.15$ & $19.47 \pm 7.29$ & .923 \\
\hline & & R-GM & $24.06 \pm 2.93$ & $44.37 \pm 6.21^{\dagger}$ & $27.53 \pm 0.75^{\dagger}$ & $47.758^{*}$ \\
\hline & & $\mathrm{R}-\mathrm{BF}$ & $6.16 \pm 3.68$ & $12.83 \pm 1.31^{\dagger}$ & $3.29 \pm 1.01^{\dagger}$ & $28.946^{*}$ \\
\hline & & R-GN & $4.72 \pm 1.61$ & $12.88 \pm 10.00^{\dagger}$ & $5.50 \pm 0.54$ & $3.845^{*}$ \\
\hline \multirow{16}{*}{$\begin{array}{l}\text { Parivrrta upavistha } \\
\text { konasana }\end{array}$} & \multirow{8}{*}{ Left } & L-ES & $86.51 \pm 12.41$ & $80.66 \pm 11.92$ & $82.49 \pm 4.40$ & .698 \\
\hline & & L-GM & $18.70 \pm 1.95$ & $8.06 \pm 0.58^{\dagger}$ & $5.76 \pm 2.48$ & $75.107^{*}$ \\
\hline & & L-BF & $17.44 \pm 4.45$ & $9.18 \pm 1.04^{\dagger}$ & $5.79 \pm 0.48$ & $34.193^{*}$ \\
\hline & & L-GN & $30.00 \pm 1.48$ & $25.86 \pm 3.86^{\dagger}$ & $19.45 \pm 0.45^{\dagger}$ & $33.891^{*}$ \\
\hline & & R-ES & $21.81 \pm 9.28$ & $11.40 \pm 3.32^{\dagger}$ & $22.16 \pm 10.52$ & 3.509 \\
\hline & & R-GM & $23.75 \pm 4.58$ & $79.83 \pm 55.40^{\dagger}$ & $30.97 \pm 8.31^{\dagger}$ & $19.740^{*}$ \\
\hline & & $\mathrm{R}-\mathrm{BF}$ & $30.83 \pm 21.57$ & $46.15 \pm 3.39^{\dagger}$ & $34.57 \pm 30.42^{\dagger}$ & $22.127^{*}$ \\
\hline & & R-GN & $7.88 \pm 4.27$ & $16.44 \pm 4.49^{\dagger}$ & $3.28 \pm 1.30$ & $40.699^{*}$ \\
\hline & \multirow{8}{*}{ Right } & L-ES & $67.81 \pm 8.90$ & $37.42 \pm 2.13^{\dagger}$ & $76.56 \pm 3.23 \dagger$ & $89.207^{*}$ \\
\hline & & L-GM & $14.10 \pm 0.83$ & $9.37 \pm 0.33^{\dagger}$ & $5.45 \pm 1.19$ & $142.031^{*}$ \\
\hline & & L-BF & $19.07 \pm 6.79$ & $8.79 \pm 0.31^{\dagger}$ & $5.67 \pm 0.14$ & $21.441^{*}$ \\
\hline & & L-GN & $28.30 \pm 0.78$ & $1.65 \pm 0.18^{\dagger}$ & $19.62 \pm 0.37$ & $4309.949^{*}$ \\
\hline & & R-ES & $40.28 \pm 9.98$ & $37.49 \pm 15.55$ & $17.71 \pm 13.33^{\dagger}$ & $4.931^{*}$ \\
\hline & & R-GM & $19.47 \pm 1.69$ & $43.62 \pm 3.31^{\dagger}$ & $30.97 \pm 8.77^{\dagger}$ & 23.662 \\
\hline & & $\mathrm{R}-\mathrm{BF}$ & $4.68 \pm 1.04$ & $7.67 \pm 0.46$ & $19.64 \pm 31.55$ & .485 \\
\hline & & R-GN & $3.77 \pm 0.27$ & $28.47 \pm 6.60^{\dagger}$ & $5.07 \pm 0.46$ & $86.815^{*}$ \\
\hline \multirow{11}{*}{$\begin{array}{l}\text { Parsva upavistha } \\
\text { konasana }\end{array}$} & \multirow{8}{*}{ Left } & L-ES & $90.68 \pm 6.99$ & $77.74 \pm 1.87^{\dagger}$ & $59.16 \pm 9.26^{\dagger}$ & $51.108^{*}$ \\
\hline & & L-GM & $13.76 \pm 1.05$ & $8.16 \pm 0.67^{\dagger}$ & $6.70 \pm 1.03$ & $91.467^{*}$ \\
\hline & & L-BF & $13.74 \pm 0.42$ & $8.65 \pm 0.81^{\dagger}$ & $10.59 \pm 5.72$ & $2.880^{*}$ \\
\hline & & L-GN & $27.78 \pm 0.71$ & $1.56 \pm 0.20^{\dagger}$ & $19.56 \pm 0.23$ & $5971.626^{*}$ \\
\hline & & R-ES & $14.30 \pm 3.47$ & $14.55 \pm 9.85$ & $9.07 \pm 1.34$ & 1.726 \\
\hline & & R-GM & $17.57 \pm 1.68$ & $37.84 \pm 1.39^{\dagger}$ & $28.25 \pm 1.23$ & $290.172^{*}$ \\
\hline & & $\mathrm{R}-\mathrm{BF}$ & $14.41 \pm 6.19$ & $8.99 \pm 2.19 \dagger$ & $9.41 \pm 1.35^{\dagger}$ & $3.855^{*}$ \\
\hline & & R-GN & $3.83 \pm 0.41$ & $22.59 \pm 2.46^{\dagger}$ & $5.60 \pm 0.43^{\dagger}$ & $325.589^{*}$ \\
\hline & \multirow{3}{*}{ Right } & L-ES & $85.20 \pm 8.35$ & $41.74 \pm 6.37^{\dagger}$ & $40.33 \pm 10.34$ & $82.578^{*}$ \\
\hline & & L-GM & $14.16 \pm 1.38$ & $8.19 \pm 0.98^{\dagger}$ & $5.00 \pm 0.39$ & $143.359^{*}$ \\
\hline & & L-BF & $13.62 \pm 0.46$ & $8.26 \pm 0.29^{\dagger}$ & $6.04 \pm 0.96$ & $197.560^{*}$ \\
\hline
\end{tabular}

Values are means \pm SD. ${ }^{*} \mathrm{p}<.05,+\mathrm{p}<.05$ vs. CON. L: left R: right, ES: erector spine, GM: glutes medius, BF: biceps femoris, GL: gastrocnemius. 


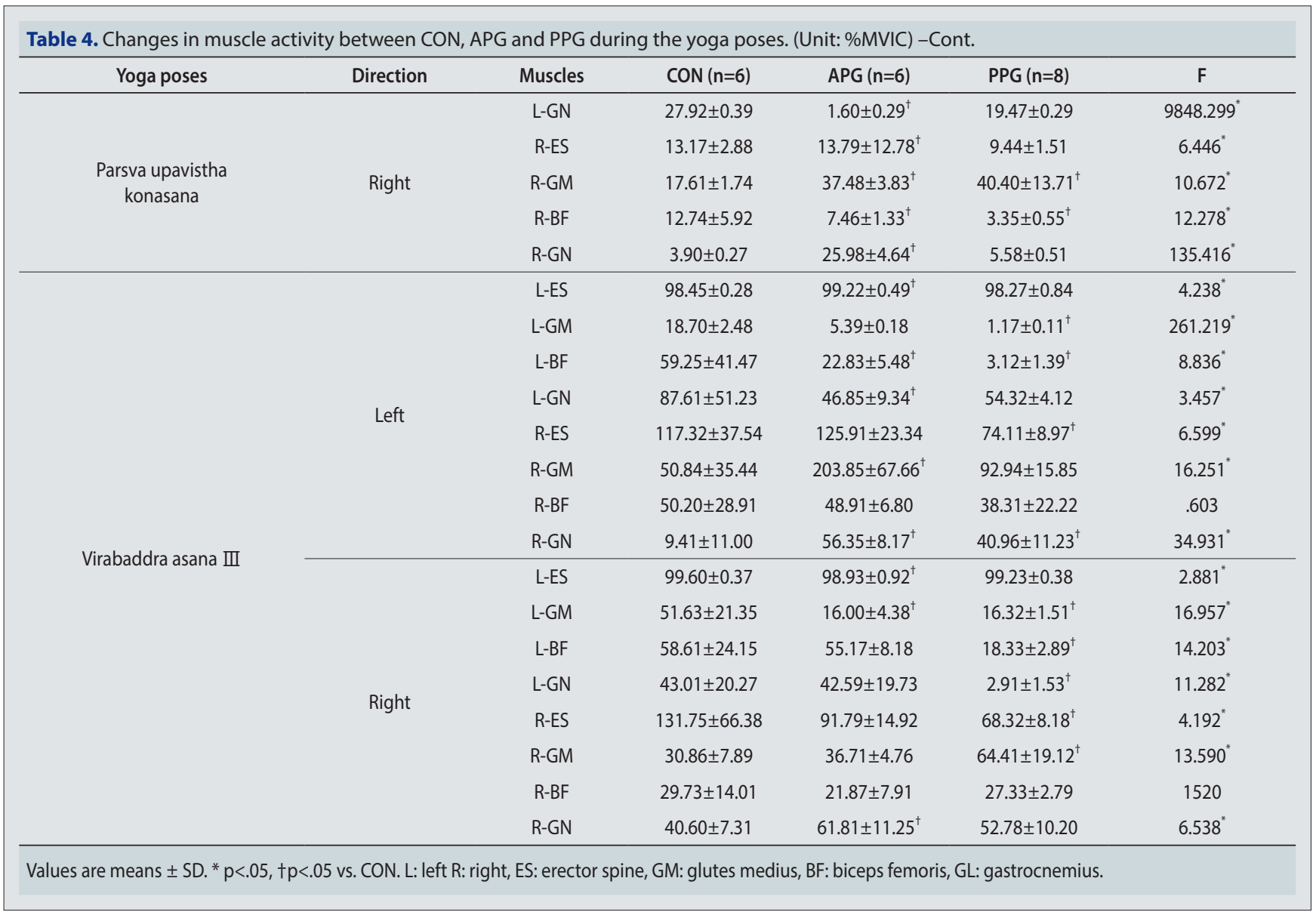

$\mathrm{R}-\mathrm{BF}(\mathrm{p}=.000)$ 의 근활성도는 $\mathrm{CON}$ 과 비교해서 $\mathrm{PPG}$ 에서 유의하게 낮게 나타났다. 왼쪽 Parivrrta upavistha konasana 동작 중 $\mathrm{R}-\mathrm{GM}(\mathrm{p}=.000), \mathrm{R}-\mathrm{BF}(\mathrm{p}=.001)$ 및 $\mathrm{R}-\mathrm{GN}(\mathrm{p}=.000)$ 의 근활성도는 $\mathrm{CON}$ 과 비교해서 $\mathrm{APG}$ 에서 각각 유의하 게 높게 나타났으며, 반면에 $\mathrm{L}-\mathrm{GM}(\mathrm{p}=.000), \mathrm{L}-\mathrm{BF}(\mathrm{p}=.000)$, $\mathrm{L}-\mathrm{GN}(\mathrm{p}=.007)$ 및 $\mathrm{R}-\mathrm{ES}(\mathrm{p}=.025)$ 의 근활성도는 $\mathrm{CON}$ 과 비 교해서 $\mathrm{APG}$ 에서 각각 유의하게 낮게 나타났다. 또한 $\mathrm{R}-\mathrm{GM}(\mathrm{p}=.042)$ 및 $\mathrm{R}-\mathrm{BF}(\mathrm{p}=.000)$ 의 근활성도는 $\mathrm{CON}$ 과 비 교해서 PPG에서 각각 유의하게 높게 나타났으며, 반면에 $\mathrm{L}-\mathrm{GN}(\mathrm{p}=.000)$ 의 근활성도는 $\mathrm{CON}$ 과 비교해서 $\mathrm{PPG}$ 에서 유의하게 낮게 나타났다. 오른쪽 Parivrrta upavistha konasana 동작 중 $\mathrm{R}-\mathrm{GM}(\mathrm{p}=.002)$ 및 $\mathrm{R}-\mathrm{GN}(\mathrm{p}=.000)$ 의 근활성도 는 $\mathrm{CON}$ 과 비교해서 $\mathrm{APG}$ 에서 각각 유의하게 높게 나타 났으며, 반면에 L-ES(p=.000), L-GM(p=.000), L-BF(p=.000) 및 $\mathrm{L}-\mathrm{GN}(\mathrm{p}=.000)$ 의 근활성도는 $\mathrm{CON}$ 과 비교해서 $\mathrm{APG}$ 에 서 각각 유의하게 낮게 나타났다. 또한 $\mathrm{R}-\mathrm{ES}(\mathrm{p}=.011)$ 및 $\mathrm{R}-\mathrm{GM}(\mathrm{p}=.003)$ 의 근활성도는 $\mathrm{CON}$ 과 비교해서 $\mathrm{PPG}$ 에서 각각 유의하게 높게 나타났으며, 반면에 $\mathrm{L}-\mathrm{GN}(\mathrm{p}=.000)$
의 근활성도는 $\mathrm{CON}$ 과 비교해서 $\mathrm{PPG}$ 에서 유의하게 낮게 나타났다. 왼쪽 parsva upavistha konasana 동작 중 $\mathrm{R}-\mathrm{GM}(\mathrm{p}=.000)$ 및 $\mathrm{R}-\mathrm{GN}(\mathrm{p}=.000)$ 의 근활성도는 $\mathrm{CON}$ 과 비 교해서 $\mathrm{APG}$ 에서 각각 유의하게 높게 나타났으며, 반면에 $\mathrm{L}-\mathrm{ES}(\mathrm{p}=.002), \mathrm{L}-\mathrm{GM}(\mathrm{p}=.000), \mathrm{L}-\mathrm{BF}(\mathrm{p}=.029), \mathrm{L}-\mathrm{GN}(\mathrm{p}=.000)$ 및 $\mathrm{R}-\mathrm{BF}(\mathrm{p}=.024)$ 의 근활성도는 $\mathrm{CON}$ 과 비교해서 $\mathrm{APG}$ 에 서 각각 유의하게 낮게 나타났다. 또한 R-GN(p=.000)의 근 활성도는 $\mathrm{CON}$ 과 비교해서 $\mathrm{PPG}$ 에서 유의하게 높게 나타 났으며, 반면에 $\mathrm{L}-\mathrm{ES}(\mathrm{p}=.000)$ 및 $\mathrm{R}-\mathrm{BF}(\mathrm{p}=.032)$ 의 근활성도 는 $\mathrm{CON}$ 과 비교해서 $\mathrm{PPG}$ 에서 각각 유의하게 낮게 나타났 다. 오른쪽 parsva upavistha konasana 동작 중 R-ES(p=.024), $\mathrm{R}-\mathrm{GM}(\mathrm{p}=.002)$ 및 $\mathrm{R}-\mathrm{GN}(\mathrm{p}=.000)$ 의 근활성도는 $\mathrm{CON}$ 과 비 교해서 $\mathrm{APG}$ 에서 각각 유의하게 높게 나타났으며, 반면에 $\mathrm{L}-\mathrm{ES}(\mathrm{p}=.000), \mathrm{L}-\mathrm{GM}(\mathrm{p}=.000), \mathrm{L}-\mathrm{BF}(\mathrm{p}=.000), \mathrm{L}-\mathrm{GN}(\mathrm{p}=.000)$ 및 $\mathrm{R}-\mathrm{BF}(\mathrm{p}=.000)$ 의 근활성도는 $\mathrm{CON}$ 과 비교해서 $\mathrm{APG}$ 에서 각각 유의하게 낮게 나타났다. 또한 $\mathrm{R}-\mathrm{GM}(\mathrm{p}=.000)$ 의 근활 성도는 $\mathrm{CON}$ 과 비교해서 $\mathrm{PPG}$ 에서 유의하게 높게 나타났 으며, 반면에 $\mathrm{R}-\mathrm{BF}(\mathrm{p}=.000)$ 의 근활성도는 $\mathrm{CON}$ 과 비교해 
서 PPG에서 유의하게 낮게 나타났다. 왼쪽 Virabaddra asa$\mathrm{na} I I I$ 동작 중 $\mathrm{L}-\mathrm{ES}(\mathrm{p}=.004)$ 및 $\mathrm{R}-\mathrm{GM}(\mathrm{p}=.011)$ 의 근활성도 는 $\mathrm{CON}$ 과 비교해서 $\mathrm{APG}$ 에서 각각 유의하게 높게 나타났 으며, 반면에 $\mathrm{L}-\mathrm{GM}(\mathrm{p}=.000), \mathrm{L}-\mathrm{BF}(\mathrm{p}=.001)$ 및 $\mathrm{L}-\mathrm{GN}(\mathrm{p}=.000)$ 의 근활성도는 $\mathrm{CON}$ 과 비교해서 $\mathrm{APG}$ 에서 각각 유의하 게 낮게 나타났다. 또한 R-GL(p=.000)의 근활성도는 $\mathrm{CON}$ 과 비교해서 PPG에서 유의하게 높게 나타났으며, 반면에 $\mathrm{L}-\mathrm{GM}(\mathrm{p}=.000)$ 및 $\mathrm{L}-\mathrm{BF}(\mathrm{p}=.014)$ 의 근활성도는 $\mathrm{CON}$ 과 비교 해서 PPG에서 각각 유의하게 낮게 나타났다. 오른쪽 Virabaddra asana III 동작 중 R-GN(p=.002)의 근활성도는 CON 과 비교해서 $\mathrm{APG}$ 에서 유의하게 높게 나타났으며, 반면에 $\mathrm{L}-\mathrm{ES}(\mathrm{p}=.030)$ 의 근활성도는 $\mathrm{CON}$ 과 비교해서 $\mathrm{APG}$ 에서 유 의하게 낮게 나타났다. 또한 R-GM(p=.000)의 근활성도는 $\mathrm{CON}$ 과 비교해서 $\mathrm{PPG}$ 에서 유의하게 높게 나타났으며, 반 면에 L-GM(p=.000), L-BF(p=.000), L-GN(p=.001) 및 R-ES$(\mathrm{p}=.012)$ 의 근활성도는 $\mathrm{CON}$ 과 비교해서 $\mathrm{APG}$ 에서 각각 유의하게 낮게 나타났다.

\section{논의}

이 연구에서는 골반변위에 따른 요가 동작이 중년여성 의 척추 관절가동범위, 위뒤엉덩뼈가시의 높이 및 근활성 도에 미치는 영향을 검토하였다. 그 결과, 골반변위가 있 는 중년여성의 요가 동작은 척추 관절가동범위, 위뒤엉덩 뼈가시의 높이 및 근활성도에 부정적인 영향을 미치는 것 을 확인하였다.

Kendall et al. (2005)은 균형적인 움직임은 관절과 근육 간에 적절한 조절을 통해 신체의 구조와 기능을 긍정적으 로 유지한다고 보고하였으며, Lee (2001)은 근골격계의 균 형 조절은 신체분절 사이의 생체역학적 관계에서 관절가 동범위 및 근육의 특성을 포함한다고 하였다. 일반적으로 요가 동작은 몸통 굽힘과 폄의 동작이 많으며, 굽힘 동작 은 신체의 뒷다리(hind limb), 허리(lumbar), 등(back) 및 목 (neck)을 펴는 동작으로써 척추 및 골반의 관절이 앞으로 굽혀지는 동작이 대부분이다. 이 연구에서 요가 동작 중 척추 관절가동범위는 오른쪽 Janusirsa asana 중에 몸통 오 른쪽 굽힘과 골반 기울임에서 $\mathrm{CON}$ 과 비교해서 $\mathrm{APG}$ 및 $\mathrm{PPG}$ 에서 유의하게 낮게 나타났다. 이는 요가 동작이 한 방향으로 움직이는 상태에서도 오른쪽과 왼쪽의 쓰임이 다를 수 있음을 알 수 있는 결과라고 생각된다. Janusirsa asana는 척추에서는 경미한 굽힘이 일어나고 골반과 엉치
엉덩관절에서 보다 많은 굽힘이 일어나는 동작으로써 습 관적으로 몸의 한쪽을 사용하는 측면성을 나타내기 때문 에 굽힌 다리 쪽의 엉치엉덩관절의 가동성이 큰 경우, 몸 통을 편 다리 쪽으로 굽히는 것이 수월해진다고 알려져 있 다(Leslie, 2007). 따라서 이 연구에서 요가 동작 중 척추의 관절가동범위와 골반 기울임이 APG 및 PPG 모두 오른쪽 에서만 유의하게 낮게 나타나는 편측성 움직임을 보인 것 은 생활 속습관적인 비대칭적 사용과 골반변위로 인해 엉 치엉덩관절 굽힘의 움직임에 제한이 있기 때문일 것이라 고 생각된다.

이 연구에서 Parivrrta upavistha konasana 중 오른쪽 골반 기울임은 $\mathrm{CON}$ 과 비교해서 $\mathrm{APG}$ 및 PPG에서 낮게 나타났 다. 이는 습관적인 비대칭성과 동시에 골반의 변위로 인한 엉덩관절 가동범위의 제한과 엉덩관절 벌림 근육인 중간 볼기근과 엉덩관절 폄근인 넙다리 두갈래근의 불균형으 로 인해 궁둥뼈결절이 지면에서 닿은 상태에서 반대쪽으 로 힘을 발휘하기 어려워 한쪽으로 치우친 결과 엉덩관절 의 기울임이 낮게 나타났다고 생각된다. 이처럼 이 연구에 서 척추 관절가동범위는 요가 동작 중에서만 $\mathrm{APG}$ 및 PPG 모두 불균형한 움직임을 나타냈다. 이것은 골반이 중립에 위치해 있을 때 동적인 자세에서 안정적으로 상체와 하체 의 관절과 근육을 조절하고 유지하여 동작을 행하는 능력 을 증진시킬 수 있다고 보고(Seo et al., 1996)한 선행연구의 내용과 일치한다고 생각된다. 따라서 요가 동작은 신체의 정렬, 즉 골반의 중립상태를 유지할 수 있도록 적절한 지 도가 필요할 것으로 생각된다.

한편, 이 연구에서 요가 동작에 따라 골반 변위 대상자 의 위뒤엉덩뼈가시의 높이가 차이를 보인 것은 요가 동작 시 사용되는 척추세움근, 넙다리두갈래근 및 중간볼기근 의 불균형이 발생하였기 때문인 것으로 생각된다. 이 연구 에서 요가 동작 중의 근활성도는 $\mathrm{CON}$ 과 비교해서 $\mathrm{APG}$ 에 서 척추세움근, 넙다리두갈래근, 중간볼기근 및 장딴지근 에서 보다 높은 차이를 보였다. 또한 Janusirsa asana의 근 육 작용은 접힌 다리 쪽에서 넙다리두갈래근의 단축성 수 축과 장딴지근의 신장성 수축이 발생하고, 편 다리쪽에 서 넙다리두갈래근 및 중간볼기근의 신장성 수축과 장딴 지근의 단축성 수축이 발생 하는데, 이 연구에서 왼쪽 Janusirsa asana 동작 중에 왼쪽 척추세움근, 중간볼기근, 넙 다리두갈래근 및 장딴지근의 활성도는 $\mathrm{CON}$ 과 비교해서 $\mathrm{APG}$ 에서 낮게 나타났으며, 오른쪽에서는 높게 나타났다. 특히, 척추 관절가동범위에서 유의한 차이를 보인 오른쪽 
의 경우, 접힌 다리 쪽의 장딴지근의 근활성도는 $\mathrm{CON}$ 과 비교해서 $\mathrm{APG}$ 에서 낮게 나타났으며, 반대로 편 다리 쪽에 서 높게 나타났다. 또한 장딴지근의 활성도는 $\mathrm{CON}$ 과 비 교해서 PPG에서 높게 나타났지만, PPG에 비해 APG에서 보다 높게 나타났으며, 중간볼기근 및 넙다리두갈래근의 활성도도 $\mathrm{CON}$ 및 PPG와 비교해서 $\mathrm{APG}$ 에서 높게 나타났 다. 이러한 결과, 즉 $\mathrm{APG}$ 의 경우 장딴지근, 중간볼기근 및 넙다리두갈래근이 길어지거나 약화된 근육이기 때문에 보다 많이 기울이기 위해서 보다 많은 힘이 발현됐을 것으 로 생각된다. 선행연구에 의하면, 관절가동범위는 근육이 나 인대 등 관절을 이루거나 관계가 있는 여러 구조물 등 의 움직임에 의해 결정이 된다고 보고하였다(Cho, 1995). Parivrrta upavistha konasana 및 Parsva upavistha konasana 중 근활성도는 $\mathrm{APG}$ 의 왼쪽 몸통의 왼쪽에서는 $\mathrm{CON}$ 과 비교 해서 낮게 나타났으며, 오른쪽에서는 CON과 비교해서 높 게 나타났다. 이 동작에서 근육의 작용은 중간볼기근, 넙 다리두갈래근 및 장딴지근에서 신장성 수축이 발생하고, 두 동작 모두 다리를 좌우로 벌리고 두 다리를 편 상태로 행하기 때문에 신장성 수축 시 근활성도가 $\mathrm{CON}$ 과 비교해 서 $\mathrm{APG}$ 에서 높게 나타난 것으로 추측된다. 왼쪽 Virabaddra asana III 동작 시 왼쪽 근육군의 활성도는 $\mathrm{CON}$ 과 비교 해서 $\mathrm{APG}$ 에서 낮게 나타났으며, 오른쪽 근육군의 활성도 는 $\mathrm{CON}$ 과 비교해서 $\mathrm{APG}$ 에서 높게 나타났다. 하지만 위 뒤엉덩뼈가시의 높이에서 차이를 보인 오른쪽을 살펴보 면, $\mathrm{CON}$ 과 비교해서 지지하는 다리 쪽에서 넙다리두갈래 근의 활성도는 유의한 차이가 없지만, 엉덩관절의 굽힘을 조절하고 골반의 수평을 유지하는 중간볼기근의 활성도 는 $\mathrm{CON}$ 및 $\mathrm{PPG}$ 과 비교해서 $\mathrm{APG}$ 에서 높게 나타났다. 이 연구에서 근활성도는 오른쪽과 완쪽의 불균형이 있다는 것을 확인하였다. 따라서 골반변위에 따른 요가 동작이 중 년여성의 지속적인 골반의 기울임과 비대칭을 형성할 수 있고, 유연성 및 근력의 저하를 초래할 수 있다는 가능성 이 시사되었다.

많은 선행연구에 의하면, 균형과 기능적 움직임은 밀 접한 관련성이 있으며(Bohannon, 1991; Haart et al., 2004; Sarah et al., 2006), 불균형 상태에서 반복되는 생활과 습관 은 나쁜 자세를 만들고(Cailliet, 1994; Mun, 2004), 유연성 의 감소와 통증 및 운동제한으로 인해 결국에는 뼈와 연부 조직의 변화를 초래한다고 보고하였다(Hwang et al., 1994; Park, 1997; David et al., 1999). 또한 성인의 경우에는 몸통 및 다리에서 편측성(laterality)활동이 많으며(Boldori et al.,
1999), 이러한 편측성 활동은 일상생활의 활동 수준을 저 하시킬 수 있다고 보고하였다(Kim, 2015). 따라서 요가 동 작은 골반의 중립 상태에서 골반 주변의 근육과 관절들을 균형 있게 사용할 필요가 있다고 생각된다.

\section{결론}

이 연구에서는 골반변위에 따른 요가 동작이 중년여성 의 척추 관절가동범위, 위뒤엉덩뼈가시의 높이 및 근활성 도에 미치는 영향을 검토한 결과, 골반변위가 있는 중년여 성의 요가 동작은 $\mathrm{CON}$ 과 비교하여 척추 관절가동범위와 위뒤엉덩뼈가시의 높이에서 유의하게 낮게 나타났으며, 근활성도는 더 많은 유의차를 보였다. 이상의 결과, 골반 변위가 있는 중년여성과 정상여성간의 요가동작은 차이 가 있는 것을 확인하였다. 향후에는 골반의 고정 여부에 따른 요가 동작의 생체역학적 및 근역학적 영향을 검토할 필요가 있다고 생각된다.

\section{Conflicts of Interest}

The authors declare no conflict of interest.

\section{References}

Aiengar B.K.C. (2007). Yoga : Yoga dipika.

Bae, S., Kim, TY, \& Bae, J. H. (1999). A comprehensive kinematic approachto pelvis. The Journal of Korean Physical Therapy, 11(2), 93-102.

Oken, M.C. Salinski, S.M. Elsas. (2006). Vigilance, alertness, or sustained attention: physiological basis and measurement, 117 (9), 1885-1901.

Bohannon RW. (1991). Relationship among paretic knee extension strength, maximum weightbearing, and gait speed in patients with stroke. Journal of Stroke and Cerebrovascular Diseases, 1, 65-69.

Boldori, L., Dal Solda M., \& Marelli, A. (1999). Anomalies of the trunk. An analysis of their prevalence in young athletes. Minerva Pediatr, 5(1), 259-264.

Cailliet. (1994). Low back pain syndrome.

Choi, E. A. (2007). Yoga teaching method. Seoul.

Choi, E. A. (2008). The effect of Hatha yoga practice to dis- 
placed pelvis correction of middle aged women. Changwon National University.

Cho, Y. H. (1995). Health activities for the aged, Seoul.

Clark, J. M., \& Haynor, DR. (1987). Anatomy of the abductormuscles of the hipasstudied by computed tomography. The Journal of Bone \& Joint Surgery, 69(7), 1021-1031.

Dalstra, M., \& Huiskes, R. (1995). Load transfer across the pelvic bone. Journal of Biomechanics, 28(6), 715-724.

David G. Simons, Janet G. Travell, Lois S. Simons. (1999). Myofascial pain and dysfunction: the trigger point manual, Vol. 1 Upper Half of Body.

DN.,\& Cirulli, J. (1994). Pelvic stabilization during resistance training: Its effect on the development of lumbar extension strength. Archives of Physical Medicine and Rehabilitation, 75, 210-215.

Faul, F., Erdfelder, E., Lang, A. G., \& Buchner, A. (2007). $\mathrm{G}^{\star}$ Power 3: A flexible statistical power analysis program for the social, behavioral, and biomedical sciences. Behavior Research Methods, 39(2), 175-191.

Hwang, C. M., Kim, H. S., Ahn, K. H. (1994). Segmental and dermatomal somatosensory evoked potentials in lower extremity of normal adult. The Journal of Korean Academy of Rehabilitation Medicine, 18(2), 234-241

Hwang, J. K. (2005). The effect of low back stretching exercise on lumbar lordosis angle, sit-up and modified visual analogue scale in loe back pain patients, Dankook University.

Graves, JE., Webb, DC., Pllock, ML., Matkozich, J., Leggett, SL., Carpenter, DM. (1990). Quantitative assessment of full range-of-motion isometric lumbar extension strength. Spine. 15(4), 289-294.

Haart M, Geurts AC, Huidekoper SC. (2004). Recovery of standing balance in postacute stroke patients: a rehabilitation cohort study. Archives of Physical Medicine and Rehabilitation, 85, 886-895.

Harris-Hayes, M., Sahrmann, SA., \& Van Dillen, LR. (2009). Relationship between the hip and low back pain in athletes who participate in rotation-related sports. Journal of Sport Rehabilitation, 18(1), 60-75.

Lee, H. S. (2015). Enhanced muscle activity during lumbar extension exercise with pelvic stabilization. Journal of
Exercise Rehabilitation, 11(6), 372-377.

Kang, Y.H., kim, S. C. (2011). Change of morphologic pelvis and deviation according to gender, age -radiological pelvimetry. Korean Society of Radiological Science, 34(2), 91-96.

Kendall, FP., McCreary, FP., \& Provance, PG. (1993). Muscles: testing and function. Baltimore.

Kendall, FP., McCreary, FP., \& Provance, PG. (2005). Muscles: testing and function with posture and pain. Baltimore.

Kimberly Anne., Williamsa., John Petronisb., David Smithc., David Goodrichd., Juan Wue. (2005). Effect of Iyengar yoga therapy for chronic low back pain. Pain, 115, 107-117.

Kim, D. D., Kim., M. H., Kim, Y. H., Mun, S. E., Mun, S. K. (2009). Measurement and evaluation. Seoul.

Kim, J. H. (2007). An influence of trunk control using pelvic movement upon the foot pressure of patient with hemiplegia. (Dissertation of Master's degree). Yong-in university, Yong-in, Republic of Korea. The Journal of Korean Physical Therapy, 19, 9-11.

Kim, J. H., Jang, S. K. (2014). The Effects of Robo-horseback riding with changes of pelvic tilting and speeds on muscle activities of trunk and lower limb, 26(5), 290-295

Kim, S. J., Lee, S. H., Kim, W. S., Lee, E. H., Park, Y. H., Na, J. K. (1997). Analysis of increased myotatic reflex in children with spastic cerebral palsy. Annals of Rehabilitation Medicine. 23(3), 524-530.

Kim, W. M. (2015). The effects of pelvic stabilization exercise program on the lumbopelvic subluxation and posture balance ability for chronic low back pain patients with malalignment syndrome, The graduate school of Hanyang university.

Kim, Y., Kim, S., \& Jang, H. (2014). Correlation of hip joint range of motion and femur head anterior glide mobility with gait ability in stroke patients. Journal of Korean Society of Physical Medicine. 9(1), 35-44.

Kong, SW., Jeong, Y. W., \& Kim, J. Y. (2015). Correlation between balance and gait according to pelvic displacement in stroke patients. Journal of Physical Therapy Science, 27(7), 2171-2174.

Lee, H, S. (2001). A study of standing balance control between 
normal subjects and subjects with low back pain. Taegu university.

Lee, H. S. (2014). Effects of lumbopelvic stabilization exercise on lumbosacral region angle, dynamic balance, trunk extensor endurance and pain index in chronic low back pain patients) (Effects of lumbopelvic stabilization exercise on lumbosacral region angle, dynamic balance, trunk extensor endurance and pain index in chronic low back pain patients. Korean Journal of Sports Science, 23(2), 993-1005.

Leslie kaminoff., \& Amy matthews. (2007). Yoga anatomy.

Leslie Kaminoff. (2011). Yoga Anatomy Edition.

Levine., Michael W., Whittl. (1997). Three-dimensional relationships between the movements of the pelvis and lumbar spine during normal gait. Human Movement Science, 18(5), 682-692.

Min, K. W. (2005). Therapeuiic exercise. Seungnam.

Mun, S. E. (2004). General coordinative manipulation. Seoul.

Myers, TW., Chaitow, L., \& Juhan, D. (2001). Anatomy trains: Myofacial meridians for manual and movement therapists. Churchill Livingstone, Edinburgh.

Neumann, D. A. (2002). Kinesiology of the musculoskeletal system.

Nooij, R. D., Kallenberg, L. A. C. \& Hermens, H. J.(2009). Evaluating the effect of electrode location on surface EMG amplitude. Journal of Electromyography and Kinesiology. 19, 257-266.

Osamu Wada, Hiroshige Tateuchi, Noriaki Ichihashi. (2014). The correlation between movement of the center of mass and the kinematics of the spine, pelvis, and hip joints during body rotation. Gait \& Posture, 39(1), 6064.

Post, WR., Teitge, R., \& Amis, A. (2002). Patellofemoral malalignment: looking beyond the viewbox. Clinical Sports Medicine, 21(3), 521-546.

Park, C. B., Park, S. Y. (2004). Exercise of anatomy \& physiology. Seoul.

Park, Y. H. (1997). The visual analysis of myofascial syndrome on balance posture. The Journal of Korean Society of Physical Therapy, 9(1), 177-184.

Park, Y. H., Kim, D. H. (2016). Effects of Iyengar yoga practice for 12 weeks on lower body imbalance in middle-aged women. Journal of the Korea Academia-Industrial Cooperation Society, 18(1), 431-440.

Sarah F Tyson, Marie Hanley, Jay Chillala, Andrea Selley, Raymond C Tallis. (2006). Balance disability after stroke. Physical Therapy, 86(1), 30-38.

Sahrmann S A. (2002). Movement science and physical therapy. Journal of Physical Education, Recreation \& Dance. $7,4-7$.

Schamberger, W. (2012). The malalignment syndrome. second edition. Elsevier Limited.

Seo, K. W., Ba, S. S., Shin, H. C. (1996). Change of the pelvic tilt angle on bobath approach in hemiplegic patients. The journal of Korean Academy of Physical Therapist, 3(1), 123-130.

Tak, A. Y. (2011). The effect of yoga exercises for junior high school girl's posture and health-related physical fitness. Kyungsung university.

Waryasz, G. R. (2010). Excercise strategies to prevent the development of the anterior pelvic tilt: Implications for possible prevention of sports hernias and osteitis pubis. The Journal of Strength \& Conditioning Research, 32(4), 56-65.

Youdas, J. W., Garrett, T. R., Harmsen, S., Suman, V. J., \& Carey, J. R. (1996). Lumbar lordosis and pelvic inclination of asymptomatic adults. Physical Therapy Journal, 76(10), 1066-1081.

You, S., Lee, J. H., You, S. S. (2010). Connective mechanism using muscle activity in half vinyasa. Korean Society for Wellness, 6, 3.

Yun, S. J., Back, S. H., Shin, M. H., Kim, D. S. (2009). Effects of yoga training and BCAA amino acid in take on physical strength and body shape in middle-aged women. Korean Education Journal of Aesthetic Society, 7(3), 175-185. 